\title{
Cooperative Learning Approach in Learning MTA Surakarta High School Students
}

\author{
${ }^{1}$ Sawitri, ${ }^{2}$ Andayani, ${ }^{3}$ Kundharu Saddhono \\ ${ }^{1}$ sawitri.mta@gmail.com, ${ }^{2}$ bu_anda09@yahoo.co.id, ${ }^{3}$ kundharu@uns.ac.id \\ 1,2,3,4 Sebelas Maret University Surakarta
}

\begin{abstract}
The study, entitled "Cooperatie Learning Approach at Short Story Learning for Students of Class XI SMA MTA Surakarta" raised the problem of how planning, implementation, and learning outcomes of reading short stories by using a cooperative learning approach in SMA MTA Surakarta students. This study aims to describe the planning, implementation, and learning outcomes of reading short stories using a cooperative learning approach. The source of this research data was obtained from Indonesian teachers and students of class XI IPA-4 SMA MTA Surakarta. The method used is descriptive method with a qualitative approach. Data collection is done by observation and data processing techniques by analyzing the learning implementation plan that has been prepared by the teacher, implementing the learning that has been observed, and learning outcomes based on the assessment that the teacher gives. The results of the data analysis showed that the RPP compiled by the teacher contained several errors, however, the learning process took place quite well, and the assessment of the results of learning to read short stories with a cooperative learning approach was satisfactory with an average value of 84. Thus, the average student class XI IPA-4 SMA MTA Surakarta. Learning to read short stories with a cooperative learning approach based on the results of this study is good. It is suggested that research related to reading learning can be continued by other researchers so that it can obtain another picture as an effort to improve student learning outcomes.
\end{abstract}

Keywords: cooperativeve learning approach, short story, descriptive.

\section{Introduction}

In essence, Indonesian language learning is directed to sharpen students' feelings of sensitivity. Teachers are required to be able to motivate their students so that they can increase their reading interest in literature, especially short stories, because by studying literature it is expected that students can draw various benefits from their lives. Various efforts can be done, one of which uses the Cooperative Learning approach in learning to read short stories. Reading activity is an effort to understand the information conveyed by the writer through the writing symbol to be able to explore the information conveyed by the author. The implementation of reading activities as a skill can be seen as intellectual skills (ability) to connect elements of formal language, namely words as sounds which are connected with meanings associated with meanings symbolized by these words. Short stories here are interpreted as short readings that can be read once sitting in a short time, the genre has a single effect, characters, plots, and settings that are limited, not diverse and not complex. The short story contents determine an event in the behavior of the culprit. The story finally does not need to change the fate of the culprit. In other words, the author of the short story does not need to describe the entire lifetime of the culprit, only a part of which is chosen 
really has the meaning to be displayed. Short stories are made as an aim to give a sharp and clear picture in a single, complete form, and achieve a single effect in its reading.

Reading is one of 4 language skills. Reading skills are receptive, accepting. Reading is a process of changing the form of writing into a form of meaning. There are several meanings of reading as follows: Reading is seeing and understanding the contents of what is written both in writing or in the heart. According to Anderson reading is a process to understand the implicit and explicit, see the thoughts contained in written words[1]. According to Finochiaro and Bonomo, reading is picking and understanding the meaning or meaning contained in the written material. So it can be concluded that reading short stories is understanding as a short reading can be read once sitting in a short time, the genre has a single effect, characters, plots, and settings that are limited, not diverse and not complex, understanding what is implied and picking what contained in the written words.

Learning to read short stories (works of fiction) is indeed more interesting than learning to read nonsastra understanding (nonfiction works). However, in practice teachers often encounter obstacles in learning. Students feel bored with learning to read short stories because learning methods to read short stories are used monotonically. The short story material presented by the teacher is not interesting because the material is not related to the context of the lives of students. In addition, the ability of students' understanding and appreciation of the content of the short story is also not encouraging. Students find it difficult to appreciate short stories. This is because the teacher still uses monotonous and conventional steps to read short stories. Seeing the fact that teachers should choose innovative and fun learning methods, so that students do not feel bored following the learning to read short stories and the power of appreciation and student learning outcomes increase.

Cooperative learning is a learning that directs students to collaborate in a small group of different abilities to complete academic tasks[2]. With this kind of learning something that is difficult for individual students will find solutions through group collaboration. According to Vygotsky and Piaget (in Nur and Wikandari[3]) students will find it easier to understand difficult concepts if they work together, discuss problems with their friends. In addition, the cooperative learning approach can also foster a positive attitude towards friends. On this basis, in this paper the writer wants to present learning to read short stories with a cooperative learning approach.

\section{Literature Review}

The approach to learning is expected not only to improve students' academic abilities, but also other skills. These skills, according to Jack R. Fraenkel[4], include: a). Social skills; b). Sharing Skills; c). Participatory Skills; d). Communication Skills; e). Team Development, and; f). Group skills. Thus the combination is arranged in a particular activity that includes human dimensions, materials, facilities, equipment and procedures that influence each other to achieve learning goals. The learning approach is implemented as a process of interaction between the teacher and students where the teacher can master his knowledge, skills and attitudes that are in accordance with the learning objectives provided. So, the learning approach is the process of interaction between humans in the transfer of knowledge from those that cannot become able, from those who do not know to know and from the unusual to ordinary. This process takes place not only from educators to students, but also on the contrary educators can take lessons from their students. From the description above, it can be concluded that the learning approach is an effort or 
the way a teacher (educator) in delivering learning material with the hope that the objectives of the learning process can be achieved. In other words, the learning approach is all the efforts or methods that the teacher does in the learning process, whether formal, informal, or non-formal. [2] According to Nana Sujana, the approach used in learning is generally characterized by types: lectures, question and answer, discussion, assignment or recitation, group work, demonstrations and experiments, social drama, problem solving, team systems, training, field trips, surveys community and simulation. In accordance with the title of the study, the researcher will only explain about the implementation of the cooperative learning approach in learning the short story of class XI of SMA MTA Surakarta students.

The cooperative learning approach is one of the teaching patterns by training students in dealing with problems. Each student is trained to solve problems both alone and together, by exerting all the abilities possessed by students in the form of mind, will, feeling and enthusiasm to find out the solution to an expected conclusion. Cooperative learning with other languages, is a learning that puts students as subjects of education in solving problems. The cooperative learning approach, is part of the interactive learning model that gathers the strength and potential of each learner to participate in analyzing various situations that occur both inside and outside the classroom. This model is considered suitable for educating students who in certain cases should be considered adults, or as a maturing process. This means that it is in accordance with the purpose of education, one of which aims to mature students from the previous time which is considered immature.

From the description above, it can be concluded that the cooperative learning approach is a way of placing a teacher or educator as a subject on one side, but he stands as an object on the other side. Likewise with students. It can be placed as an object and subject in education. The cooperative learning approach is realized in the technical learning that is carried out by providing questions that contain problems for students. Something that is considered as a problem, ask to be conveyed to students or ask students to convey the problems they have. Then the problem is solved together, by accommodating every possible difference that occurs in their environment.

The purpose of this approach is applied, so that the knowledge or skills delivered are more meaningful and more powerful in the memory of each student. This is in accordance with modern education theory which mentions that what is heard, must be remembered but not long after, it becomes forgotten. But what is done, understood and remembered forever. To implement a cooperative learning approach that is good and effective, there are several things that must be considered. The matters referred to are as follows: (1). this approach must be considered most appropriate for certain learning that takes place in learning activities. And this, according to the researcher is quite suitable to do, especially for reading short stories that are likely to occur in class discussions. (2). The teacher must be sure that the approach is used with the intention to train students to think critically and dynamically, so that each learning with this model can improve the development of intelligence, students. (3). The teacher must be sure that the approach is used with the intention to train students to have an attitude of living together in the midst of all the differences that occur. This means that in the classroom must reflect what encourages democratic and broad-minded spirit to accept every difference in the student environment. (4). This form of approach can vary meaning it can take the form of questions, it can also be in the form of certain tasks or statements that allow students to be actively involved in the learning process that takes place. 
According to some experts there are various definitions of short stories, namely:Short Stories are fictional stories whose problems are clear, concise, and solid and concentrated on an event[1]. Short stories are stories that only tell one of the events rather than the entire life of the perpetrator[5]. From the above opinion it can be concluded that the short story is a short story that only tells one event clearly and densely.

Elements of Short Stories According to Sumadjo and Saini[6] in a successful short story, the theme is actually disguised in an element. The author uses the dialogues of his characters, his way of thinking, feelings, events of the story to emphasize or direct the contents of the theme. The author usually expresses the theme clandestinely, in the field of the main characters or in a story scene. A theme is a story idea that describes the basis for developing a story that animates the whole story. According to Aminudin[7], the plot is a story that is shaped by the stages of an event to form a story. While Sumardjo and Saini[6] reveal that the plot or plot consists of elements, namely recognition, emergence of conflict, peak conflict, climax, and problem solving. Characterization is an actor who carries out an event in a fiction story, so that the story is able to form a story.

Students will be asked to account individually for the material handled in the cooperative group.The characteristics of cooperative learning. Ibrahim[8] suggests the characteristics of cooperative learning as follows; 1) Students work in groups cooperatively to complete their learning material. 2) Groups are formed from students who have heterogeneous abilities (high, medium, and low). 3) Whenever possible, group members come from different races, cultures, tribes and genders. 4) Awards are more group-oriented than individuals. Cooperative learning models are developed to achieve at least three important learning goals[8], namely: 1). Cooperative learning aims to improve student academic achievement. Although cooperative learning includes a variety of social goals, cooperative learning can also be used to improve academic achievement. The developers of cooperative learning have shown that the cooperative reward structure can increase the value students get and change norms according to these achievements. 2) Receive diversity. Another goal of cooperative learning is the widespread acceptance of people of different races, cultures, social classes, abilities, and incompetence.

Cooperative learning provides opportunities for students from various backgrounds and different conditions to work together to complete the academic tasks given to them and it is expected that there will be mutual respect for each other. 3). Develop social skills. The most important goal of cooperative learning is learning the skills of working together and collaborating. These skills are important to be applied in people's lives. Steps for cooperative learning there are 6 main steps in cooperative learning as found in Ibrahim[8]the following; 1) Delivering goals and motivating students. 2) The teacher conveys the learning objectives to be achieved in the learning activities and motivates to learn. 3) Presenting information. The teacher presents information to students by demonstration or through reading material. 4) Organize students into study groups. The teacher explains to students how to form study groups and helps each group to make the transition efficiently. Cooperative learning groups consist of students with different backgrounds, ethnicities, ethnicities and levels of ability. 5) Guiding work and study groups. 5) Teachers guide each study group when they are doing assignments. 6). Evaluate learning outcomes. The teacher evaluates the learning outcomes about the material that has been studied or each group presents the learning outcomes. 7) Giving awards. The teacher seeks ways to appreciate, both individual and group learning and learning outcomes. 
To understand a short story we must examine the elements of the short story builder, such as: plot, character, and characterization, background, point of view, and meaning contained in the story. 1) Understand the groove. A story always starts and ends. Events intertwining from the beginning to the end of the story are called plot or plot. As a fruit of a series of events, the plot always displays major conflicts. Even in the groove we will encounter the peak of the conflict. These conflicts can be in the form of internal conflicts (inner conflicts / self-conflicts) and external conflicts. Internal conflict is a conflict that is felt by a character. Whereas external conflicts are human conflicts with humans, humans and nature, and humans with God. When viewed from the way the author ends the story, there are two types of grooves, namely closed grooves and open grooves. The story ends with a closed technique when this story is completely finished, leaving no further questions in the reader. The story ends with an open technique when the end of the story still leaves the reader with questions about how the fate will be received by the characters in the story. Whereas if he dies from the mood or fate of the central figure or the end of the story, the plot can be classified into two, namely the happy end and the final flow of grief. The final line is happy when the central figure finds joy / happiness at the end of the story. The flow ends with grief when the central figure finds sadness at the end of the story.

2) Understanding characters and characterizations. Figure is a groove motor. Without a plot character it will never arrive at the end of the story. There are three types of figures when viewed from the aspect of involvement in moving the plot, namely the central figure, subordinate figure, and background character. The central figure is a figure who has the potential to move the plot. It is the center of the story, the cause of the emergence of the conflict while the subordinate is a character who does not have much influence on the development of the plot, even though he is also involved in knowledge beyond that. While the background figure is a character who has no effect on the development of the plot. Its presence is only as a complementary background, functions to turn on the background.

3). Understanding the setting (setting), is a painting of a place, time relationship, and social environment where events occur (Abrams in Subyantoro[9]). The background provides a concrete and clear storyline, and is very important to give a realistic impression to the reader, create a certain atmosphere that seems to really exist. Stanton (inSubyantoro[9]) even classifies backgrounds, characters, and plots into facts (stories), because these three elements will be faced and can be imagined in factual readers if they read fiction. The setting is not only described physically, but can also be in the form of procedures, customs, beliefs, and values that apply at the scene, which can usually be called a spiritual setting. The background function is at least two, namely: 1. In order for the story to look more alive, 2. Describe the psychological situation or the inner situation of the character.

4) Understanding the point of view in the work of fiction follows: who tells or from which position (who) the event and action is seen. The choice of the form of the work of fiction involves: who tells, or from which position (who) the event and action is seen. The selection of persona forms can influence the development of stories and problems that are told, as well as freedom, limitations, sharpness, and objectivity towards the things that are told. There are two ways of viewing angles, namely the way of the first person and the way of the third person. In the way of the first person, the author will use "me / me" as the storyteller. As a result, the author seems to be a character in the story he wrote. Election The first person technique is done by the author when he wants to describe inner conflict or psychological struggle in depth. In the way of a third person, 
the author will tell the story of the third person event or experience, so the word gain used is "he / she / the name of the person". In the corner of this type of view the author really is outside the story.

5). Understanding the meaning If we read a story, we can find a new meaning when we have read the whole story. The meaning contained in a story is also called a theme (Stanton in Nurgiyantoro[10][11]. The meaning in the story can be the meaning of the character's behavior, the meaning of the conflict that develops, the meaning of the settlement, the meaning of the setting, and the meaning of the point of view.

\section{Material \& Methodology}

This study uses a qualitative approach. This research was conducted to obtain an overview of the implementation of learning to read short stories through a cooperative learning approach in class XI SMA MTA Surakarta. Qualitative descriptive research aims to find out what is happening in the observation environment, and the views of participants in the research setting and the events or activities that occur during observation. is a teacher of Indonesian studies and a class XI student of SMA MTA Surakarta. This school is located on Jl Kyai Mojo Semanggi Pasar Kliwon Surakarta. The data that will be collected in this study are learning planning, learning implementation, and learning outcomes of reading short stories using an approach.

Data collected is data sourced from lesson planning in the form of lesson plans, the process of learning implementation consists of introduction, core, and closing, as well as learning outcomes in the form of teacher's assessment of student learning processes and outcomes. The source of the data set in this study was at class XI IPA-4 SMA MTA Surakarta, which consisted of one teacher and 34 students.

Observation and documentation. Darmadi[12] states, observation is to see and record all the phenomena that appear to enable observations made by researchers during the observation process. Observation techniques are used to obtain data about implementation and resultsthe implementation of learning to write short stories with cooperative learning approach in class XI students of SMA MTA Surakarta. When learning takes place, researchersact as an observer or can be said to be nonparticipant observation. The researcher only observes and records the learning process in the prepared observation sheet. The things that are recorded on the observation sheet are the initial learning planning activities in the form of RPP, learning implementation steps and the stages of learning activities. Existing data is then analyzed and processed. The stages of processing and data analysis are as follows: 1) Analyze the learning implementation plan (RPP) that has been made by Indonesian language teachers at the research location. 2) Analyzing the implementation of learning that has been observed. 3) Analyze the results of activitieslearning. All the results of the data that has been obtained will be analyzed described and concluded qualitatively based on theoretical studies. Data analysis in qualitative research can be carried out during data collection and after completion of data collection in a certain period. After the researcher has done the steps above, the researcher will describe the data that has been analyzed in the form of an in-depth description so that it is more easily understood.

\section{Results and Discussion}

Learning Planning The results of the analysis of RPP data compiled by the teacher already have the completeness of the components needed in the preparation of RPP, such as KI, 
$\mathrm{KD}$, indicators, learning objectives, learning materials, learning resources and learning media, learning approaches and methods, learning steps, and assessment of learning outcomes. However, in planning, the lesson plans prepared by the teacher are not in accordance with the concept of learning material to write short stories using a cooperative learning approach. The core competencies in the RPP compiled by the teacher are in accordance with those stated in the syllabus, namely there are four KI that emphasize the attitudes, abilities, and skills of students that must be achieved in learning.

Furthermore, KD 2.3 that is applied in RPP is not in accordance with the material being taught. KD 2.3 should be replaced with KD 3.4 because it is related to KD 4.4 about analyzing the content and language of short stories which reads "Constructing the text of a short story that is coherent in accordance with the characteristics that will be made both orally and in writing". Thus, Reading Learning Short Story Implementation does not match the formulation of KI and KD is not in accordance with the content standards.

The indicator used is not a description of the KD that has been written. For example, the fourth indicator is not in accordance with the determined KD, namely "Students can construct a short story text with a cooperative learning approach. Thus, the formulation of the indicator does not contain the behavior to measure the achievement of KD even though the formulation of the indicator uses the operational verb. Furthermore, the learning objectives do not refer to KD because the selection of $\mathrm{KD}$ is not right. The formulation of learning objectives includes the process and student learning outcomes that are expected to be achieved, namely students can read short story texts using a cooperative learning approach. Learning material contained in the lesson plan is in accordance with what will be taught, which is about reading short stories. Learning material attached to RPP is less focused on short story text, but more about the cooperative learning approach. Actually cooperative learning approach is only a learning technique. Therefore, learning material is not in harmony with $\mathrm{KD}$ and is not in accordance with the concept of learning to read short stories.

The method used in RPP is in accordance with the material to be taught. The material taught about reading short stories using a cooperative learning approach. Learning activities have been systematically arranged by the teacher in the RPP by grouping activities according to the parts of the activity, namely preliminary activities, core activities, and closing activities. At the core activities, the teacher shares the steps of learning to observe, question, explore, communicate, and associate. The formulation of learning activities describes the activities and material that will be achieved by students in the implementation of learning. Furthermore, the assessment rubric included in the RPP is incomplete, it should consist of all aspects of reading short stories. The assessment contained in the RPP is not appropriate and does not reflect the achievement of indicators.

The above description reflects that the teacher prepares an RPP for learning to read short stories with a cooperative learning approach can be said to be less in accordance with the concept of learning Reading short stories using cooperative learning emphasis. Learning Implementation With regard to the implementation of the cooperative learning approach in learning it can be explained that it is in accordance with the implementation of the cooperative learning approach even though some parts of the material are not appropriate. Application of implementing the learning process usingcooperative learning approach makes students more active in learning, especially short story reading material, because each student gets the same role in practicing the 
learning step with a cooperative learning approach. When the learning process takes place, the activities of the teacher and students are measured using the observation sheet of the learning process. Teacher and student activities when the learning process is observed by the researcher alone.

Overall, the results of the data analysis of the implementation of learning to read short stories using a cooperative learning approach in class XI IPA-4 students of SMA MTA Surakarta in accordance with the formulation of learning steps in the RPP. Seen when the learning process is quite active in discussing groups between students. Students are active and enthusiastic about digging up information about the exposure delivered by other groups if they are unclear and when delivering the results of their group discussions. However, the obstacle faced during the learning process is only the lack of explanation given by the teacher regarding the cooperative learning approach. This makes it difficult for students to understand the learning process. Whereas in the RPP already stated / included one step clearly with an explanation of the steps of a cooperative learning approach. In addition, when explaining the steps of a cooperative learning approach, the teacher also looks unclear, but is still somewhat hesitant, making students somewhat confused. Constraints that occur when learning is covered by the principle principles used by the teacher in the learning process of writing short stories by using a cooperative learning approach that is very motivating for students, because learning requires motivation or encouragement for students to learn, an atmosphere that is supportive and enjoyable and reflective. With the principles used by the teacher students are more motivated and facilitated in the writing material taught.

Assessment of learning outcomes is very important to be done in order to determine the success rate of students after participating in learning activities. Learning outcomes using the cooperative learning approach can be said to be quite satisfying. This can be seen based on the learning outcomes of students who are enthusiastic in reading short stories. The average learning outcomes obtained by students of class XI IPA-4 using the cooperative learning approach have met the KKM score, which is 70. Although there are some students who get grades under the KKM or do not meet the KKM, this is due to students' lack of learning and laziness follow the teacher's direction when learning takes place. Conversely, students who get complete grades or above KKM by using a cooperative learning approach as a learning approach are factors that influence student success in using other learning approaches.

\section{Conclusion}

Based on the results of research and analysis of the data that has been described, it can be concluded that the use of cooperative learning approach in reading short stories by students of class XI of SMA 4 MTA Surakarta is as follows. 1) Preparation of the RPP compiled by the teacher of Indonesian language study class XI IPA-4 SMA MTA Surakarta has completed the RPP requirements but in its preparation there are some parts that are not appropriate. This is evidenced in the formulation of indicators, learning objectives, learning materials, learning methods, learning steps, and assessment rubrics. 2) Through the use of a cooperative learning approach, the activity of teachers and students during learning takes place quite actively in discussions. The use of a cooperative learning approach gives encouragement to students to be more active in learning to solve problems or apply what they learn into a problem that exists in real life. 3) Assessment of learning outcomes using the cooperative learning approach can be said to be quite satisfying. It can be seen from the students' learning outcomes that are enthusiastic when learning takes place, 
although some students are not serious when the learning process takes place. The assessment obtained by 3 students who did not complete the KKM due to their lack of seriousness and 31 students who completed the KKM.

\section{Reference}

[1] H. G. Tarigan, Reading as a Language Skill. Bandung: Angkasa Publiser, 2008.

[2] R. E. Slavin, Cooperative Learning: Theory, Research and Practice. Bandung: Nusa Media, 2015.

[3] M. and W. Nur, Pengajaran berpusat kepada siswa dan pendekata kontruktivis dalam pengajaran. Surabaya: PSMS Program Pascasarjana Unesa, 2000.

[4] J. R. F. and N. E. Wallen, How to Design and Evaluate Research in Education. San Francisco: San Francisco State University, 1960.

[5] H. G. Tarigan, Berbicara Sebagai Suatu Keterampilan Berbahasa. Jakarta: Angkasa, 2008.

[6] J. \& S. K. M. Sumardjo, Apresiasi Kesusastraan. Jakarta: Gramedia, 1997.

[7] Aminuddin, Pengantar Apresiasi Sastra. Bandung: Sinar Baru Algesindo, 1987.

[8] I. Muslimin, Characteristics of Cooperative Learning. Jakarta: Gramedia, 2000.

[9] A. Subaryanto, Metode dan Teknik Penelitian Sosial. Yogyakarta: Andi, 2006.

[10] B. Nurgiyantoro, Penilaian Pembelajaran Bahasa Berbasis Kompetensi. Yogyakarta: BPFE, 2012.

[11] B. Nurgiyantoro, Theory of Fiction Assessment. Yogyakarta: Gajah Mada University Press, 2010.

[12] H. Darmadi, Metode Penelitian Pendidikan. Bandung: Alfabeta, 2011. 